\title{
ALKALINE PROTEASES FROM THE GUT FLUIDS OF DETRITUS-FEEDING LARVAE OF THE CRANE FLY, TIPULA ABDOMINALIS (SAY) (DIPTERA, TIPULIDAE)
}

\author{
Baldev R. Sharma*, Michael M. Martin † and Jules A. Shafer* \\ *Department of Biological Chemistry and †Division of Biological Sciences, University of Michigan, Ann \\ Arbor, MI 48109, U.S.A.
}

(Received 15 April 1983; revised 4 July 1983)

\begin{abstract}
The high level of proteolytic activity present in the midgut fluids of the detritus-feeding larvae of the crane fly, Tipula abdominalis, is due to a mixture of enzymes, consisting largely of serine proteases with trypsin- or chymotrypsin-like substrate specificities. These enzymes have high alkaline pH optima $(\mathrm{pH}>11)$ and high stability at $\mathrm{pH}$ values of $8.5-11.5$ at $15^{\circ} \mathrm{C}$, properties that enable them to function effectively in the highly alkaline gut fluids (pH 9.5-11.5) of an insect that feeds and grows in cold water $\left(0-25^{\circ} \mathrm{C}\right)$. The enzymes also have very low isoelectric points $(\mathrm{pH}<6)$, resulting in their having a high negative charge in vivo. Possibly their anionic character prevents their inactivation through adsorption on ingested lignin, humic acid or clay. These serine enzymes arise from the midgut epithelial cells, and not from microbes residing in the gut or from ingested detrital food. The digestive system of $T$. abdominalis larvae is adapted for the efficient utilization of the limited quantities of dietary protein present in detrital fcod.
\end{abstract}

Key Word Index: Tipula abdominalis, Diptera, detritivores, digestive enzymes, proteinases, serine proteases, alkaline proteases, protein digestion

\section{INTRODUCTION}

Detritus is a food resource of limited nutritive value, and the growth of detritivores is generally thought to be limited by the availability of nitrogen, at least in some stages of growth (Iversen, 1974; McNeill and Southwood, 1978; Anderson and Sedell, 1979; Cummins and Klug, 1979; Mattson, 1980). The extraordinarily high levels of proteolytic activity observed in the gut fluids of detritus-feeding crane fly larvae (Diptera) (Martin et al., 1980), caddisfly larvae (Trichoptera) (Martin et al., 1981a), and stonefly nymphs (Plecoptera) (Martin et al., 1981b) attest to the importance of digestive mechanisms that permit the efficient utilization of the limited amounts of dietary protein available in the food of these insects.

Protein digestion in most insects is accomplished by a combination of serine endopeptidases, carboxypeptidases and aminopeptidases. Serine proteinases have been detected in the gut fluids of several detritus-feeding species, including larvae of the mosquitoes Aedes aegypti (Yang and Davies, 1971a,b; Kunz, 1978) and Culex pipiens (Spiro-Kern, 1974), and the sciarid fly, Rhyncosciara americana (Terra et al., 1979). Although it is common practice to refer to insect serine endopeptidases as trypsin- or chymotrypsin-like on the basis of their substrate specificities, the insect enzymes differ from their vertebrate counterparts in a number of ways, most notably in their stability and activity under highly alkaline conditions. Mosquito larvae commonly have midgut $\mathrm{pH}$ values in the range 8.5-10.5 (Dadd, 1975) whereas black fly larvae (Undeen, 1979) and crane fly larvae (Martin et al., 1980) have pH values in excess of 11 in certain regions of the midgut. Herbivorous lepidopteran larvae also have highly alkaline guts
(Berenbaum, 1980), and serine proteinases with highly alkaline $\mathrm{pH}$ optima (Lecadet and Dedonder, 1966a,b; Miller et al., 1974; Eguchi and Iwamoto, 1976; Ahmad et al., 1980; Eguchi et al., 1982).

We have explored the enzymatic basis for proteolytic activity in the midgut fluids of larvae of the crane fly, Tipula abdominalis (Say) (Diptera, Tipulidae). T. abdominalis is an abundant shredder of leaf litter in Michigan streams. Our objectives were to probe the complexity of the enzyme mixture responsible for the high levels of proteolytic activity observed under the strongly alkaline conditions that prevail in this species, and to identify the origin or origins of the enzymes present. It has been established that the capacity of several wood (Martin and Martin, 1978; Kukor and Martin, 1983) and litter-feeders (Hassall and Jennings, 1975; Bärlocher, 1982) to digest plant cell wall polysaccharides is due to fungal enzymes acquired by the ingestion of small quantities of fungal tissue. Therefore, we wanted to explore the possibility that $T$. abdominalis larvae might be acquiring their alkaline proteases from micro-organisms associated with the leaf litter that constitutes the bulk of their diet. In this study we show that proteolytic activity is due to a mixture of enzymes, consisting largely of serine proteinases with low isoelectric points and highly alkaline $\mathrm{pH}$ optima. We also show that these serine enzymes arise from the midgut epithelial tissue and are not acquired from the ingested detrital food.

\section{MATERIALS AND METHODS}

\section{Animals and detritus}

T. abdominalis larvae were collected in April and May, 1981 , and November, 1982, from naturally occurring leaf 
packs in Smith Creek (Barry County, Michigan) and in a tributary of Fleming Creek (Washtenaw County, Michigan). Larvae were transported to the laboratory in wet leaf packs at $0-5^{\circ} \mathrm{C}$, and were dissected within $24 \mathrm{hr}$ of collection. Leaves from the leaf packs, consisting of a mixture of oak, red maple, elm and willow, were frozen at $-70^{\circ} \mathrm{C}$ for the few days that intervened between collection and extraction.

\section{Preparation of extracts}

Whole midguts from 20 to 40 animals, dissected as described by Martin et al. (1980), were homogenized by hand in a glass tissue grinder in $15-30 \mathrm{ml}$ of water. The homogenate was centrifuged $\left(10,000 \mathrm{~g}, 4^{\circ} \mathrm{C}, 30 \mathrm{~min}\right)$, the pellet resuspended in $5-10 \mathrm{ml}$ of water, and the mixture centrifuged as before. The combined supernatant solutions were applied to a column of G-25 Sephadex $(4.5 \mathrm{~cm}$ i.d. $\times 22.5 \mathrm{~cm})$, and eluted with potassium phosphate buffer $(0.05 \mathrm{M}, \mathrm{pH} 7.0)$. The absorbance of the column eluent was monitored at $280 \mathrm{~nm}$, and the enzymatically active fractions were collected, pooled and frozen at $-70^{\circ} \mathrm{C}$ There was no loss of activity even after a year when the solutions were stored at $-70^{\circ} \mathrm{C}$

Midgut contents were separated from the midgut tissue by extruding the contents, still contained within the peritrophic membrane, by the careful application of pressure from a pair of forceps slid along the outside of the midgut. The midgut contents, including the peritrophic membrane, were homogenized and extracted as described above.

The midgut tissue, from which the contents and the peritrophic membrane had been removed, was carefully torn open and gently rinsed by careful agitation in a dish of water until all signs of the darkly coloured midgut fluid had been washed away. Midgut tissue with a wet weight of approx. $2.5 \mathrm{~g}$ (derived from 50 larvae), was homogenized in a glass tissue grinder with a Teflon pestle at $1500 \mathrm{rev} / \mathrm{min}$ at $0^{\circ} \mathrm{C}$. A $20 \%(\mathrm{w} / \mathrm{v})$ homogenate in $0.25 \mathrm{M}$ sucrose was centrifuged $\left(12,100 \mathrm{~g} 4^{\circ} \mathrm{C}, 30 \mathrm{~min}\right)$, the supernatant solution discarded, and the pellet resuspended in $10.0 \mathrm{ml}$ of $0.25 \mathrm{M}$ sucrose and incubated for $2 \mathrm{hr}$ at $30^{\circ} \mathrm{C}$ with an equal volume of $2 \%(\mathrm{v} / \mathrm{v})$ Lubrol WX at $\mathrm{pH} 8.95$. The resulting mixture was centrifuged $\left(12,100 \mathrm{~g}, 4^{\circ} \mathrm{C}, 10 \mathrm{~min}\right)$, and the supernatant applied to a column of G-25 Sephadex $(2.5 \mathrm{~cm}$ i.d. $\times 20 \mathrm{~cm})$, and eluted with potassium phosphate buffer $(0.05 \mathrm{M}, \mathrm{pH} 7.0)$. The absorbance of the column eluent was monitored at $280 \mathrm{~nm}$. The enzymatically active fractions were collected, pooled, and stored frozen at $-70^{\circ} \mathrm{C}$.

A detrital leaf pack extract was prepared by homogenizing $60 \mathrm{~g}$ (wet weight) of the thawed leaves in $700 \mathrm{ml}$ of chilled water for $5 \mathrm{~min}$. The extract was filtered through glass wool, and the filtrate was centrifuged $\left(10,000 \mathrm{~g}, 4^{\circ} \mathrm{C}\right.$ $30 \mathrm{~min})$. The supernatant solution $(660 \mathrm{ml})$ was concentrated to $200 \mathrm{ml}$ on a Pellicon Cassette System with a PTGC membrane, and then to $4 \mathrm{ml}$ using a stirred cell with a PM-10 membrane, and was stored frozen at $-70^{\circ} \mathrm{C}$.

\section{Enzyme assays}

General proteolytic activity was measured by following the release of dye from Azocoll (Calbiochem). Azocoll (15 mg) was suspended in $2.9 \mathrm{ml}$ of potassium phosphate buffer $(0.5 \mathrm{M})$ at $\mathrm{pH} 11.5$ (unless otherwise specified) and stirred at $37^{\circ} \mathrm{C}$ for $1 \mathrm{~min}$ for temperature equilibration. Appropriately diluted extract $(0.1 \mathrm{ml})$ containing the enzyme was then added to the substrate suspension and stirred for $15 \mathrm{~min}$ at $37^{\circ} \mathrm{C}$. At the end of this period, the reaction was terminated by the addition of $2.5 \mathrm{ml}$ of $0.01 \mathrm{M} \mathrm{HCl}$. The mixture was centrifuged in a Beckman microfuge for $2 \mathrm{~min}$ $\left(8730 \mathrm{~g}, 25^{\circ} \mathrm{C}\right)$, and the absorbance $(520 \mathrm{~nm})$ of the supernatant solution was measured. Blanks were run concurrently without the added enzyme, and the value of $A_{520}$ due to non-enzymatic release of dye into the incubation medium was subtracted from the $A_{520}$ observed in the presence of the enzymes. The value of $\Delta \hat{A}_{520}$ was a linear function of the amount of enzyme added provided the amount of Azocoll solubilized was below the amount that yielded an absorbance of 0.6. All Azocoll assays reported in this work were carried out so that the measured absorbance was proportional to the amount of enzyme added. Aminopeptidase activity was measured with L-alanyl- $\beta$-naphthylamide as substrate as described by Lee et al. (1971). Carboxypeptidase A activity was determined with hippurylL-phenylalanine as substrate as described by Davies et al. (1968). Carboxypeptidase B activity was determined with hippuryl-L-arginine as substrate as described by Folk et al. (1970). Chymotrypsin-like activity was determined with $N$-glutaryl-L-phenylalanine- $p$-nitroanilide (GPNA) (Erlanger $e$ t al., 1966) and with $N$-benzoyl-L-tyrosine ethyl ester (BTEE) (Hummel, 1959) as substrates. Trypsin-like activity was measured with $p$-tosyl-L-arginine methyl ester (TAME) (Hummel, 1959) as substrate.

The following buffers were used for determination of the pH dependence of the activity and stability of enzymes: $0.001 \mathrm{M} \mathrm{HCl}(\mathrm{pH} 3) ; 0.05 \mathrm{M}$ sodium acetate $(\mathrm{pH} 4$ and 5$)$; $0.05 \mathrm{M}$ potassium phosphate ( $\mathrm{pH} 6$ and 7 ); $0.05 \mathrm{M}$ Tris- $\mathrm{HCl}$ ( $\mathrm{pH} 8$ and 9); $0.05 \mathrm{M}$ sodium carbonate ( $\mathrm{pH} \mathrm{10);0.05} \mathrm{M}$ potassium phosphate ( $\mathrm{pH} 11.5)$.

Inhibition studies were conducted at $25^{\circ} \mathrm{C}$ using $0.1 \mathrm{mM}$ phenylmethylsulphonyl fluoride (PMSF) in isopropanol-0.05 $\mathrm{M}$ potassium phosphate buffer $(1: 9 \mathrm{v} / \mathrm{v}, \mathrm{pH} 7.0)$ or $5 \mathrm{mM}$ ethylenediaminetetra-acetate (EDTA) in $0.05 \mathrm{M}$ potassium phosphate buffer ( $\mathrm{pH} 7.0$ ).

Protein content of the various solutions could not be assayed using conventional colorimetric or tubidimetric methods (Layne, 1957) due to interference by the dark brown colour of the extracts. Instead it was necessary to calculate total protein content from amino acid analyses. Amino acid content after acid hydrolysis $(6 \mathrm{M} \mathrm{HCl}, 20 \mathrm{hr}$, $108^{\circ} \mathrm{C}$ ) was determined by the method of Koop et al. (1982).

\section{Chromatography}

The extract ( $2 \mathrm{ml}$ aliquot) of whole midguts was fractionated on a Sephadex G-100 (Pharmacia) column $(2.4 \mathrm{~cm}$ i.d. $\times 42.5 \mathrm{~cm})$, eluted with $0.1 \mathrm{M}$ Tris- $\mathrm{HCl}(\mathrm{pH} 7.0)$ at a flow rate of $24 \mathrm{ml}$ per $\mathrm{hr}$. The absorbance of the column eluent was monitored at $280 \mathrm{~nm}$, and $3-\mathrm{ml}$ fractions were collected and assayed for proteolytic activity (Azocoll), aminopeptidase activity (L-alanyl- $\beta$-naphthylamide) and chymotrypsin activity (GPNA).

\section{Electrophoresis}

Non-equilibrium pH gradient-electrophoresis (NEPHGE) was performed by the method of O'Farrel et al. (1977) as modified by Wilson et al. (1981) and Cook and Seasholtz (1982). To detect serine proteinases and esterases in native gels, samples $(100 \mu \mathrm{l})$ in $0.01 \mathrm{M}$ potassium phosphate buffer $(\mathrm{pH} 8)$ were stirred for $30 \mathrm{~min}$ with $20 \mu \mathrm{l}$ of propylene glycol containing $35 \mu \mathrm{g} / \mathrm{ml}$ of tritiated di-iso propyl fluorophosphate $\left(1,3-\left[{ }^{3} \mathrm{H}\right]\right.$-DFP, $5.2 \mathrm{Ci} / \mathrm{mmol}$, New England Nuclear) For denatured gels, the 1,3- $\left[{ }^{3} \mathrm{H}\right]-\mathrm{DFP}$-treated samples were stirred for $2-3 \mathrm{~min}$ at $80-100^{\circ} \mathrm{C}$ with $100 \mu \mathrm{I}$ of a solution of urea $(1 \mathrm{~g} / \mathrm{ml})$ and $15 \mu 1$ of 2-mercaptoethanol. Gels were fixed by immersion for $1-1.5 \mathrm{hr}$ in $10 \%(\mathrm{w} / \mathrm{v})$ trichloroacetic acid, $10 \%(\mathrm{v} / \mathrm{v})$ acetic acid, and $30 \%(\mathrm{v} / \mathrm{v})$ methanol. The gels were impregnated for $1 \mathrm{hr}$ with Enhance (New England Nuclear), and then gently treated with water for $1 \mathrm{hr}$. The treated gels were dried on a gel drier at $60-70^{\circ} \mathrm{C}$ for $2 \mathrm{hr}$ and placed against a Kodak X-ray film at $-70^{\circ} \mathrm{C}$ for 24 to $160 \mathrm{hr}$ before developing.

\section{RESULTS AND DISCUSSION}

\section{Enzymatic activity}

High levels of general proteolytic activity, assayed using Azocoll, are present in aqueous extracts of full 
Table 1 . Activity of midgut contents, midgut tissue and detrital food of $T$. abdominalis larvae toward various protease substrates (ND = not determined)

\begin{tabular}{|c|c|c|c|c|c|c|}
\hline \multirow[b]{2}{*}{$\begin{array}{l}\text { Enzymatic activity } \\
\text { (substrate) }\end{array}$} & \multirow[b]{2}{*}{$\begin{array}{c}T \\
\left({ }^{\circ} \mathrm{C}\right)\end{array}$} & \multirow[b]{2}{*}{$\mathrm{pH}$} & \multicolumn{4}{|c|}{ Activity (Units*/mg protein) } \\
\hline & & & $\begin{array}{l}\text { Midgut tissue } \\
\text { plus contentst }\end{array}$ & $\begin{array}{l}\text { Midgut } \\
\text { contents }\end{array}$ & $\begin{array}{l}\text { Midgut } \\
\text { tissue }\end{array}$ & $\begin{array}{l}\text { Detrital } \\
\text { food }{ }^{\dagger}\end{array}$ \\
\hline $\begin{array}{l}\text { General protease } \\
\text { (Azocoll) }\end{array}$ & 37 & 11.5 & 18,200 & 19,500 & 9600 & $0 \S$ \\
\hline $\begin{array}{l}\text { Aminopeptidase } \\
\text { (L-alanyl- } \beta \text {-naphthylamide) }\end{array}$ & 25 & 7.0 & 0.35 & 0.35 & 23.0 & ND \\
\hline $\begin{array}{l}\text { Trypsin } \\
\text { (TAME) }\end{array}$ & $\begin{array}{l}25 \\
25\end{array}$ & $\begin{array}{l}8.1 \\
9.1\end{array}$ & $\begin{array}{l}10.1 \\
16.9\end{array}$ & $\begin{array}{l}\text { ND } \\
\text { ND }\end{array}$ & $\begin{array}{l}\text { ND } \\
\text { ND }\end{array}$ & $\begin{array}{l}\text { ND } \\
\text { ND }\end{array}$ \\
\hline $\begin{array}{l}\text { Chymotrypsin } \\
\text { (BTEE) }\end{array}$ & 25 & 7.8 & 3.75 & ND & ND & ND \\
\hline $\begin{array}{l}\text { Chymotrypsin } \\
\text { (GPNA) }\end{array}$ & $\begin{array}{l}25 \\
25 \\
25 \\
25\end{array}$ & $\begin{array}{r}7.6 \\
8.5 \\
9.5 \\
10.0\end{array}$ & $\begin{array}{l}0.028 \\
0.077 \\
0.20 \\
0.26\end{array}$ & $\begin{array}{l}\text { ND } \\
\text { ND } \\
\text { ND } \\
\text { ND }\end{array}$ & $\begin{array}{l}\text { ND } \\
\text { ND } \\
\text { ND } \\
\text { ND }\end{array}$ & $\begin{array}{l}\text { ND } \\
\text { ND } \\
\text { ND } \\
\text { ND }\end{array}$ \\
\hline $\begin{array}{l}\text { Carboxypeptidase } \mathbf{A} \\
\text { (hippuryl-L-phenylalanine }\end{array}$ & 25 & 7.5 & $0 \$$ & ND & ND & ND \\
\hline $\begin{array}{l}\text { Carboxypeptidase B } \\
\text { (hippuryl-L-arginine) }\end{array}$ & 25 & 7.65 & $0 \xi$ & ND & ND & ND \\
\hline
\end{tabular}

* One unit of activity toward Azocoll is the amount of enzyme required to bring about a change of absorbance at $520 \mathrm{~nm}$ of 0.001 absorbance units per minute under the assay conditions. One unit of activity in all other assays is the amount of enzyme required to hydrolyze $1 \mu \mathrm{mol}$ of substrate per minute under the conditions of the assay. Recorded values are the average of duplicate determinations that differed by less than $5 \%$. †Aqueous extract. $\$$ Lubrol WX extract. \$Minimum level detectable: general protease assay, $49 \mathrm{U} / \mathrm{mg}$ protein; carboxypeptidase $A$ assay, $0.5 \mathrm{U} / \mathrm{mg}$ protein; carboxypeptidase $B$ assay, $4.8 \mathrm{U} / \mathrm{mg}$ protein.

midguts, in midgut contents contained within the peritrophic membrane but removed from the midgut tissue, and in Lubrol extracts of midgut tissue washed free of any midgut contents (Table 1). The $\mathrm{pH}$ profile of proteolytic activity (Fig. 1) shows that optimum activity toward Azocoll occurs at a pH above 11, in agreement with earlier findings (Martin et al., 1980). These highly alkaline $\mathrm{pH}$ optima are compatible with the conditions of the larval midgut, where $\mathrm{pH}$ values range from 9.5 to 11.5 . The alkaline conditions that prevail in the midgut enable the proteinases present to function at 50 to $100 \%$ of their maximum capacity.

In addition to exhibiting high activity under alkaline conditions, the midgut proteinases also exhibit remarkable resistance to autodigestion and base induced deactivation at high $\mathrm{pH}$ values. At $15^{\circ} \mathrm{C}$, a temperature at which the proteinases exhibit significant activity toward Azocoll (Martin et al.,

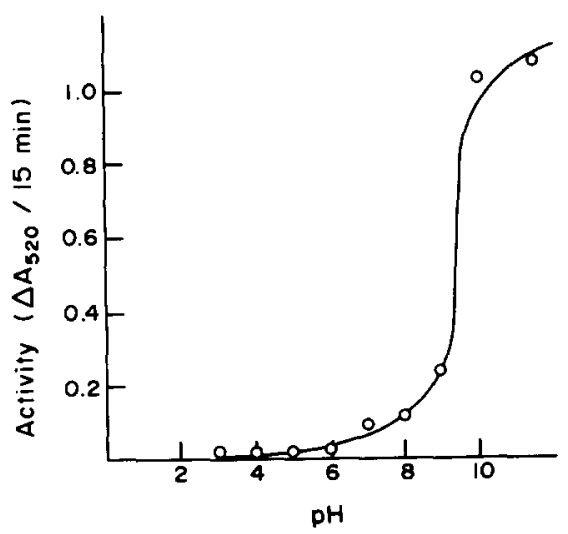

Fig. 1. Typical curve showing dependence of general proteolytic activity in an extract of whole, full midguts from $T$. abdominalis on $\mathrm{pH}$.
1980), the midgut enzymes retain 93 to $99 \%$ of their activity after $6 \mathrm{hr}$ at $\mathrm{pH}$ values of 8.0 to 11.5 , a range that encompasses the extremes of $\mathrm{pH}$ normally encountered in the midgut (Table 2). Even after $26 \mathrm{hr}$, losses in activity are small at alkaline $\mathrm{pH}$ values, especially at $\mathrm{pH} 9.0$. The enzymes are less stable at $\mathrm{pH} 7.0$ and 6.0. At $37^{\circ} \mathrm{C}$, a temperature to which the insects are never exposed in nature, the enzymes are less stable, but still exhibit impressive stability, especially at $\mathrm{pH} 8.0$ and 9.0. Since the larvae of $T$. abdominalis feed and grow during the cold months of autumn, winter and early spring, the stability of the enzymes to alkaline conditions at low temperatures is of obvious adaptive significance.

The activity of the whole midgut extract toward Azocoll is due primarily to serine proteases, as indicated by the observation that more than $70 \%$ of the general protease activity is abolished by treatment of
Table 2. Residual activity ( $\%$ ) of midgut proteinase activity of $T$. abdominalis larvae (assayed using Azocoll) after incubation at different conditions of temperature and $\mathrm{pH}(\mathrm{ND}=$ not deter-

\begin{tabular}{cccccc}
\multicolumn{5}{c}{ mined) } \\
\hline \multirow{7}{*}{$T$} & & \multicolumn{3}{c}{ Incubation time (hr) } \\
\cline { 3 - 6 }$\left({ }^{\circ} \mathrm{C}\right)$ & $\mathrm{pH}$ & 2 & 4 & 6 & 26 \\
\hline 15 & 6 & 86 & 78 & 69 & 39 \\
& 7 & 96 & 95 & 74 & 61 \\
& 8 & 97 & 96 & 94 & 93 \\
& 9 & 99 & 99 & 99 & 99 \\
& 10 & 100 & 96 & 95 & 79 \\
& 11.5 & 99 & 98 & 93 & 69 \\
37 & 6 & 69 & 68 & 54 & ND \\
& 7 & 86 & 80 & 69 & ND \\
& 8 & 86 & 86 & 86 & ND \\
& 9 & 95 & 95 & 81 & ND \\
& 10 & 90 & 78 & 62 & ND \\
& 11.5 & 29 & 23 & 17 & ND \\
\hline
\end{tabular}

* Recorded values are the average of duplicate determinations that differed by less than $4 \%$ 


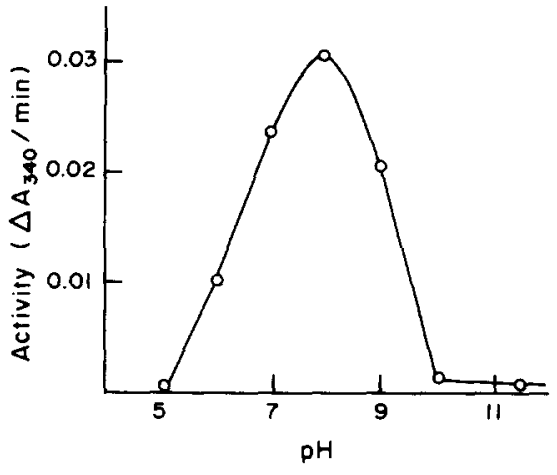

Fig. 2. Typical curve showing dependence of aminopeptidase activity in an extract of whole, full midguts from T. abdominalis on $\mathrm{pH}$.

the crude enzyme extract with $0.1 \mathrm{mM}$ PMSF at $\mathrm{pH} 7$ for $30 \mathrm{~min}$ at $25^{\circ} \mathrm{C}$. Activity toward Azocoll is not affected by EDTA. The nature of the enzymes responsible for the residual activity remaining after treatment with PMSF has not been investigated.

Aminopeptidase activity is detectable at low levels in aqueous extracts of full, intact midguts and of midgut contents (Table 1). EDTA inhibits the aminopeptidase activity in a time-dependent fashion, suggesting that the enzymes might contain tightly bound metal ions which are necessary for activity. Much higher levels of activity are present in Lubrol extracts of midgut tissue, indicating that the enzymes responsible for this activity are present in, or are bound to, the midgut epithelial cells. In larvae of the sciarid fly, $R$. americana, (Ferreira and Terra, 1982) and in adult females of the mosquito, Aedes aegypti (Graf and Briegel, 1982), it has also been demonstrated that aminopeptidases, detected using aminoacyl- $\beta$ naphthylamide substrates, are associated with the epithelial cells lining the midgut or midgut caecae. The optimal $\mathrm{pH}$ of 8.0 for aminopeptidase activity (Fig. 2) is compatible with a cellular, as opposed to a luminal, location for these enzymes. Aminopeptidases of insects are generally believed to be true peptidases, not proteinases, and to function in the terminal stages of protein digestion (Ward, 1975; Baker and Woo, 1981; Ferreira and Terra, 1982; Graf and Briegel, 1982).

Activity toward TAME, BTEE and GPNA is readily detected in an aqueous extract of full, intact midguts (Table 1). Thus, in common with other detritus-feeding dipteran larvae (Yang and Davies, 1971a,b; Spiro-Kern, 1974; Kunz, 1978; Terra et al., 1979), indeed in common with most other insects, $T$. abdominalis has serine proteases with trypsin- or chymotrypsin-like specificities. Although complete $\mathrm{pH}$-profiles for activity toward these trypsin and chymotrypsin substrates could not be determined due to the instability of the substrate and/or the formation of a precipitate at high $\mathrm{pH}$, activity clearly increases with increasing alkalinity. The $\mathrm{pH}$ at which activity is maximal is beyond the $\mathrm{pH}$ range accessible to the assays. No activity could be detected toward hippuryl-L-phenylalanine ( $\mathrm{pH}$ 7.5) or hippurylL-arginine ( $\mathrm{pH} 7.65)$, which are synthetic substrates for carboxypeptidase A and carboxypeptidase B, respectively.

\section{Enzyme multiplicity}

Gel exclusion chromatography on Sephadex G-100 indicated that the extract of full, whole midguts contained a mixture of enzymes (Fig. 3). General protease activity eluted in at least three broad peaks, while aminopeptidase and chymotrypsin activity each eluted in two peaks.

The complexity of the mixture of proteinases present was further revealed by treating an extract of whole, full midguts with $1,3-\left[{ }^{3} \mathrm{H}\right]-\mathrm{DFP}$, subjecting the mixture to non-equilibrium $\mathrm{pH}$ gradient electrophoresis (NEPHGE) and visualizing labelled serine enzymes autoradiographically. Both proteases and esterases would be visualized by this technique. At least 20 enzyme bands can be detected on denatured gels, most of them with pI values below 6.0 (Fig. 4). The zymograms from extracts of whole, full midguts and of midgut contents are indistinguishable.

\section{Origin(s) of the serine enzymes}

No activity toward Azocoll could be detected in an aqueous extract of the leaf detritus on which the larvae had been feeding (Table 1), indicating that ingested enzymes do not contribute significantly to the high levels of general protease activity present in the gut fluids. Furthermore, NEPHGE zymograms (denatured gels) of 1,3-[ $\left[{ }^{3} \mathrm{H}\right]$-DFP-treated serine enzymes derived from the gut contents of larvae collected in November and larvae collected in April or May are indistinguishable. Such constancy in the enzyme mixture present in the midgut fluids also argues against their acquisition from the detrital food, since the composition of the microbial commu-

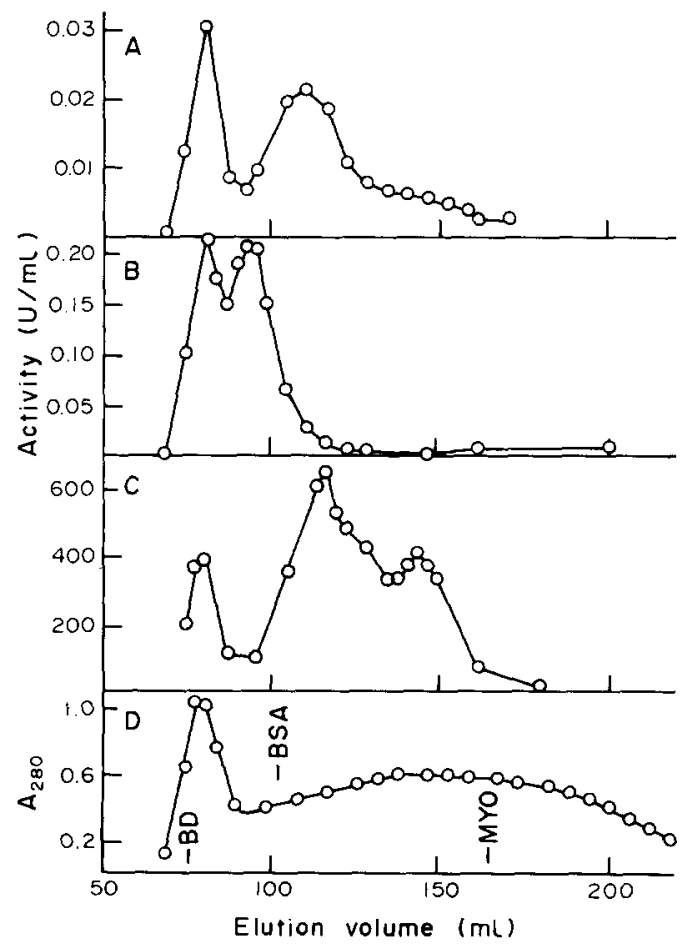

Fig. 3. Sephadex G-100 gel exclusion chromatography of an extract of whole, full midguts from $T$. abdominalis: (A) chymotrypsin activity; (B) aminopeptidase activity; (C) general proteolytic activity; (D) $\mathbf{A}_{280}$. 
A B

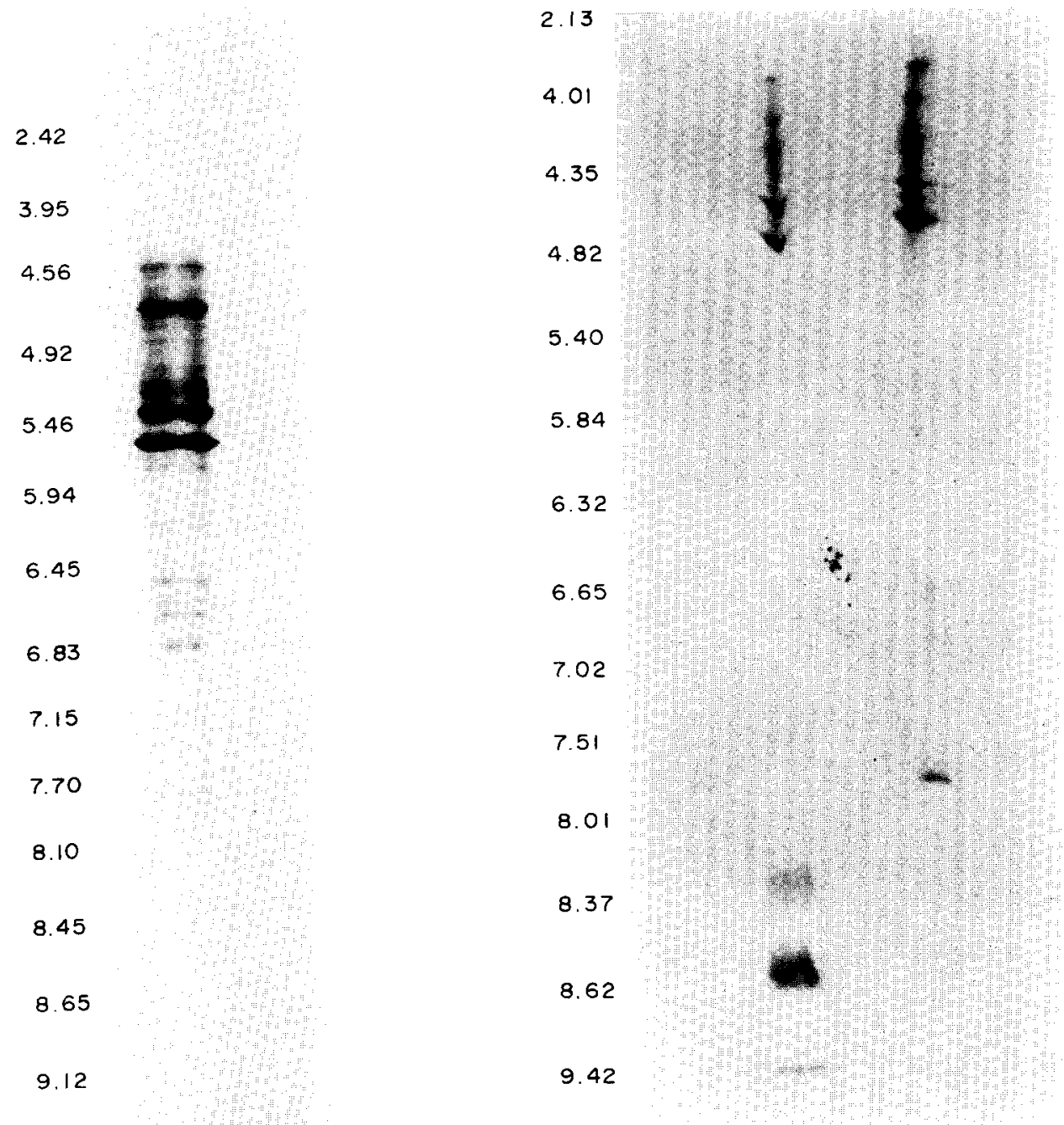

Fig. 5. Zymograms of serine enzymes in extracts from $T$. abdominalis, labelled with $1,3-\left[{ }^{3} \mathrm{H}\right]-\mathrm{DFP}$ subjected to NEPHGE (native gels): (A) Lubrol WX extract of midgut tissue; (B) midgut contents. A small distortion in the $\mathrm{pH}$ gradient established in the gel plate resulted in a displacement of bands in $A$ with respect to the corresponding ones in $\mathrm{B}$. The correspondence of the bands in $\mathrm{A}$ and $\mathrm{B}$ is indicated by iso-pH contours between $\mathrm{pH} 4.35$ and 4.82 . These were produced by the lateral diffusion of small quantities of the serine enzymes in the sample. 

nity of detritus, which is the potential source of detrital enzymes, is not constant. Thus, it is highly unlikely that the same microbial enzymes would be present in leaf packs derived from newly fallen leaves blown into streams in November and in overwintered leaves in more advanced stages of decomposition in April or May.

In order to ascertain whether midgut tissue is the source of the serine proteinases present in the gut fluid, NEPHGE zymograms (native gels) of 1,3-[ $\left.{ }^{3} \mathrm{H}\right]$-DFP-labelled serine enzymes in midgut contents and in a Lubrol extract of midgut tissue were compared (Fig. 5). All but one of the enzymes present in the midgut contents are also present in the Lubrol extract of midgut tissue. Only a single enzyme with a pI of 7.8 from the gut contents is not evident in the gut tissue. Since there are very few bacteria attached to the walls of $T$. abdominalis midguts (Klug and Kotarski, 1980), and since bacteria have not been detected in the gut cells of tipulids (Buchner, 1965), it is reasonable to suggest that the serine proteases in the midgut fluids of $T$. abdominalis larvae are secreted by the cells of the insect's midgut epithelium. Eguchi et al. (1982) have recently demonstrated that alkaline proteases present in the midgut fluids of Bombyx mori also originate in the midgut tissues.

It is interesting to note that most of the serine enzymes in the midgut fluids of $T$. abdominalis have isoelectric points below $\mathrm{pH} 6$. Since the midgut digestive fluid of this species is highly alkaline, these enzymes will bear high negative charge densities in vivo. It is possible that the anionic character of the proteases is adaptive, since it could serve to minimize adsorption of the enzymes on ingested lignin, humic acid, or clay.

Acknowledgements - This research was supported by grants from the United States Public Health Service to J. A. Shafer (AM 09276) and from the National Science Foundation to M. M. Martin (DEB80-22634). We thank Peter Becker, Mike Klug, Jerry Kukor, Dan Lawson, Joan Martin and Wes Nollenberg for technical assistance.

\section{REFERENCES}

Ahmad Z., Saleemuddin M. and Siddi M. (1980) Purification and characterization of three alkaline proteases from the gut of the larvae of army worm, Spodoptera litura. Insect Biochem. 10, 667-673.

Anderson N. H. and Sedell J. R. (1979) Detritus processing by macroinvertebrates in stream ecosystems. A. Rev. Ent. 24, 351-377.

Bärlocher F. (1982) The contribution of fungal enzymes to the digestion of leaves by Gammarus fossorum Koch. Oecologia 52, 1-4.

Baker J. E. and Woo S. M. (1981) Properties and specificities of a digestive aminopeptidase from larvae of Attagenus megatoma (Coleoptera: Dermestidae). Comp. Biochem. Physiol. 69B, 189-193.

Berenbaum M. (1980) Adaptive significance of midgut $\mathrm{pH}$ in larval Lepidoptera. Am. Nat. 115, 138-146.

Buchner P. (1965) Endosymbiosis of Animals with Plant Microorganisms. Interscience, New York.

Cook K. S. and Seasholtz A. F. (1982) identification of some bacteriophage T4 prereplicative proteins on two dimensional gel patterns. J. Virol. 42, 767-772.

Cummins K. W. and Klug M. J. (1979) Feeding ecology of stream invertebrates. A. Rev. Ecol. Syst. 10, 147-172.
Dadd R. H. (1975) Alkalinity within the midgut of mosquito larvae with alkaline-active digestive enzymes. J. Insect Physiol. 21, 1847-1853.

Davies R. C., Riordan J. F., Auld D. S. and Valee B. L. (1968) Kinetics of carboxypeptidase A. I. Hydrolysis of carbobenzoxyglycyl-L-phenylalanine and hippurylDL- $\beta$-phenyllactic acid by metal substituted and acetylated carboxypeptidases. Biochemistry 7, 1090-1099.

Eguchi M. and Iwamoto A. (1976) Alkaline proteases in the midgut tissue and digestive fluid of the silkworm, Bombyx mori. Insect Biochem. 6, 49l-496.

Eguchi M., Iwamoto A. and Yamauchi K. (1982) Interrelation of proteases from the midgut lumen, epithelia and peritrophic membrane of the silkworm, Bombyx mori L. Comp. Biochem. Physiol. 72A, 359-363.

Erlanger B. F., Edel F. and Cooper A. G. (1966) The action of chymotrypsin on two new chromogenic substrates. Archs Biochem. Biophys. 115, 206-210.

Ferreira C. and Terra W. R. (1982) Properties of arylamidases found in cytosol, microvilli and in luminal contents of Rhynchosciara americana midgut caecae. Insect Biochem. 12, 413-417.

Folk J. E., Piez K. A., Carrol W. R. and Gladner J. A. (1970) Carboxypeptidase B. IV. Purification and characterization of the porcine enzymes. J. biol. Chem. 235, 2272-2277.

Graf R. and Briegel H. (1982) Comparison between aminopeptidase and trypsin activity in blood-fed females of Aedes aegypti. Revue suisse Zool. 89, 845-850.

Hassall M. and Jennings J. B. (1975) Adaptive features of gut structure and digestive physiology in the terrestrial isopod Philoscia muscorum (Scopoli) 1973. Biol. Bull. 49, 348-364.

Hummel B. C. W. (1959) A modified spectrophotometric determination of chymotrypsin, trypsin and thrombin. Can. J. Biochem. Physiol. 37, 1393-1399.

Iversen T. M. (1974) Ingestion and growth in Sericostoma personatum (Trichoptera) in relation to the nitrogen content of ingested leaves. Oikos 25, 278-282.

Klug M. J. and Kotarski S. (1980) Bacteria associated with the gut tract of larval stages of the aquatic cranefly, Tipula abdominalis (Diptera, Tipulidae). Appl. Environ. Microbiol. 40, 408-416.

Koop D., Morgan E. T., Tarr G. E. and Coon M. J. (1982) Purification and characterization of a unique isozyme of cytochrome P-450 from liver microsomes of ethanol treated rabbits. J. biol. Chem. 257, 8472-8480.

Kukor J. J. and Martin M. M. (1983) Acquisition of digestive enzymes by siricid woodwasps from their fungal symbiont. Science 220, 1161-1163.

Kunz P. (1978) resolution and properties of the proteinases in the larvae of the mosquito, Aedes aegypti. Insect Biochem. 8, 43-51.

Layne E. (1957) Spectrophotometric and turbidimetric methods for measuring proteins. In Methods of Enzymology (Edited by Colowick S. P. and Kaplan N. O.), Vol. 3, pp. 447-454. Academic Press, New York.

Lecadet M. M. and Dedonder R. (1966a) Les protéases de Pieris brassicae. I. Purification et propriétes. Bull. Soc. Chim. biol. 48, 631-660.

Lecadet M. M. and Dedonder R. (1966b) Les protéases de Pireris brassicae II.-Spécificité. Bull. Soc. Chim. biol. 48, 661-691.

Lee H., LaRue J. N. and Wilson I. B. (1971) A simple spectrophotometric assay for aminoacyl arylamidases (naphthylamidases, aminopeptidases). Analyt. Biochem. 41, 397-401.

Martin M. M. and Martin J. S. (1978) Cellulose digestion in the midgut of the fungus-growing termite Macrotermes natalensis: the role of acquired digestive enzymes. Science 199, 1453-1455.

Martin M. M., Martin J. S., Kukor J. J. and Merritt R. W. (1980) The digestion of protein and carbohydrate by the 
stream detritivore, Tipula abdominalis (Diptera, Tipulidae). Oecologia 46, 360-364.

Martin M. M., Kukor J. J., Martin J. S., Lawson D. L. and Merritt R. W. (1981a) Digestive enzymes of larvae of three species of caddisflies (Trichoptera). Insect Biochem. 11, 501-505.

Martin M. M., Martin J. S., Kukor J. J. and Merritt R. W. (1981b) The digestive enzymes of detritus-feeding stonefly nymphs (Plecoptera; Pteronarcyidae). Can. J. Zool. 59, 1947-1951.

Mattson W. J. (1980) Herbivory in relation to plant nitrogen content. A. Rev. Ecol. System. 11, 119-161.

McNeill S. and Southwood T. R. E. (1978) The role of nitrogen in the development of insect/plant relationships. In Biochemical Aspects of Plant and Animal Coevolution (Edited by Harborne J. B.), pp. 77-99. Academic Press, New York.

Miller M. W., Kramer K. J. and Law J. H. (1974) Isolation and partial characterization of the larval midgut trypsin from the tobacco hornworm, Manduca sexta, Johannson (Lepidoptera: Sphingidae). Comp. Biochem. Physiol. 48B, 117-129.

O'Farrel P. Z., Goodman H. M. and O'Farrel P. H. (1977) High resolution two dimensional electrophoresis of basic as well as acidic proteins. Cell 12, 1133-1142.
Spiro-Kern A. (1974) Untersuchungen über die Proteasen bei Culex pipiens. J. comp. Physiol. 90, 53-70.

Terra W. R., Ferreira C. and de Bianchi A. G. (1979) Distribution of digestive enzymes among the endo- and ectoperitrophic spaces and midgut cells of Rhynchosciara and its physiological significance. J. Insect Physiol. 25, 487-494.

Undeen A. H. (1979) Simuliid larval midgut pH and its implications for control. Mosquito News 39, 391-392.

Ward C. W. (1975) Aminopeptidases in webbing clothes moth larvae. Properties and specificities of the enzymes of intermediate electrophoretic mobility. Biochim. biophys. Acta 410, 361-369.

Wilson J. M., Baugher B. W., Landa L. and Kelly W. N. (1981) Human hypoxanthine-guanine phosphoribosyltransferase. Purification and characterization of mutant forms of the enzyme. J. biol. Chem. 256 , 10306-10312.

Yang Y. J. and Davies D. M. (1971a) Trypsin and chymotrypsin during metamorphosis in Aedes aegypti and properties of the chymotrypsin. J. Insect Physiol. 17, $117-131$.

Yang Y. J. and Davies D. M. (1971b) Digestive enzymes in the excreta of Aedes aegypti larvae. J. Insect Physiol. 17, 2119-2123. 